\title{
Organiserad brottslighet, ekonomisk brottslighet och terrorism - hänger de samman?
}

\author{
Av Per Ole Träskman ${ }^{1}$
}

\begin{abstract}
This article considers the connection between "organized crime«, " economic crime" and »terrorism«. Is there empirical evidence of cases in which the true purpose of organized criminality was to commit terrorism and/or where economic criminality was committed with the purpose of financing or otherwise facilitating terrorist crimes?

These three forms of criminality are often linked in official EU documents. But is there any empirical evidence for such a connection in the Nordic countries Denmark, Finland and Sweden?

The empirical part of the article is an analysis of the annual reports of the secret service agencies of these three states. The result is - in short-negative. Indications are given for why these three forms of crime are often linked in official EU documents.

Frågan är om det finns ett samband mellan de tre formerna av brottslighet och hur detta samband $i$ så fall ser ut. Har den organiserade brottsligheten $i$ vissa fall som sitt egentliga syfte att bedriva terrorism, och är det kanske så att avsikten med ekonomisk brottslighet $i$ en del fall i själva verket är att möjliggöra terroråtgärder? Vad finns det för belägg om sambandet överhuvudtaget mellan de tre formerna för brottslighet?*
\end{abstract}

\section{Inledning}

Detta är en liten undersökning om tre former av aktuell brottslighet, organiserad brottslighet, ekonomisk brottslighet och terrorism. Valet av tema kan motiveras med att dessa tre former av brottslighet alla har varit i rätts- och kriminalpolitiskt fokus under de senaste decennierna. Detta framgår inte minst av de prioriteringar som har gjorts inom EU när det gäller den gemensamma inriktningen för brottskontroll - eller snarare om vi tar till oss den terminologi som har vunnit framsteg inom EU - brottsbekämpningen. Åtgärder för att »bekämpa« organiserad (grän-

* Title in English: Organized crime, economic crime and terrorism - are they connected? 
söverskridande) brottslighet, terrorism och vissa former av ekonomisk brottslighet ska ha hög prioritet inom EU.

Frågan är om det finns ett samband mellan de tre formerna av brottslighet och hur detta samband i så fall ser ut. Har den organiserade brottsligheten i vissa fall som sitt egentliga syfte att bedriva terrorism, och är det kanske så att avsikten med ekonomisk brottslighet i en del fall i själva verket är att möjliggöra terroråtgärder? Vad finns det för belägg om sambandet överhuvudtaget mellan de tre formerna för brottslighet?

Innehållet i denna artikel bygger inte $\mathrm{i}$ någon nämnvärd grad på empiriska undersökningar och alls inte på egna, självständiga undersökningar av verkligheten. Att utföra denna typ av undersökningar är helt uppenbart en svår uppgift och förmodligen omöjlig för en enskild forskare. Detta beror bl.a. på att en mycket stor del av den information som möjligen finns om terrorism inte är offentlig. Här är man tvungen att ty sig till källor som inte är särskilt precisa eller fullständiga. Men artikeln kan kanske inspirera till forskningsupplägg som avser fördjupad forskning inom området. Vad avser vi när vi använder oss av de tre begreppen, organiserad brottslighet, ekonomisk brottslighet och terrorism, hur ser den överordnande brottskontrollen ut när det gäller dessa brottslighetsformer och finns det något påvisat samband mellan den brottslighet som i officiella dokument placeras under någon av dessa tre etiketter.

Artikeln behandlar inte förhållandena $i$ alla nordiska länder. Vad som berörs är särskilt Danmark, Finland och Sverige.

\section{Den ekonomiska brottslighetens intåg: En tudelning mellan organiserad kriminalitet och ekonomisk kriminalitet}

På den nordiska kriminalpolitiska scenen gjorde den ekonomiska brottsligheten sitt egentliga intåg på 1970-talet. När det gäller Sverige finns följande beskrivning av intåget i Sven-Åke Lindgrens bok om ekonomisk brottslighet: ${ }^{2}$

Det var således först under 1970-talet som mer uppmärksammade problematiseringar av affärstransaktioner och skattemanipulationer kom att fogas samman under beteckningen ekonomisk brottslighet. Det första svenska initiativet kan dateras till 1973 då justitieminister Lennart Geijer vid det europeiska justitieministermötet i Stockholm krävde internationella insatser mot miljöbrott och företagsbrott bland multinationella företag. Men det var inte förrän året därpå som den offentliga debatten på allvar tog fart. Då sändes en del TV-program i de »avslöjande« programserierna »Rikets affärer« och »Fokus«, vilka handlade om skumma fastighetsbolag och deras ljusskygga affärer, svarta och vita pengar som fördes ur landet för att investeras på Kanarieöarna, Mr X och den organiserade brottsligheten i Stockholm som inför en passiv poliskår sysslade 
med affärsmässig brottslighet (bilhandel, lån med ockerräntor, bordellverksamhet under täckmantel av massageinstitut, narkotikasmuggling, bulvanaffärer med ädelstenar och pälsar mm.).

Efter detta togs ett antal initiativ för att förbättra brottskontrollen avseende ekonomiska brott. Rikspolisstyrelsen tillsatte år 1976 en arbetsgrupp mot organiserad och ekonomisk brottslighet (AMOB), på åklagarsidan tillsattes en arbetsgrupp med uppgift att skapa bättre förutsättningar för att bekämpa kvalificerad ekonomisk kriminalitet och också i Stockholm tillsattes en kommunal utredning om organiserad och ekonomisk kriminalitet. I slutet av 1970-talet publicerades en rapport om spaningsmetoder författad av en arbetsgrupp wangående spaning mot ekonomisk brottslighet $\ll$ (SPANEK). ${ }^{3}$

En hel del av diskussionen och debatten vid denna tid handlade om definitioner. Vad menas egentligen med »ekonomisk brottslighet« och vad avses med »organiserad brottslighet «. Detta var en fråga som mycket handlade om var de nya prioriterade brottskontrollerande insatserna egenligen skulle sättas in. Till en början fanns det en tydlig sammanblandningen mellan de två begreppen. ${ }^{4}$ Men med tiden gjordes en klar tudelning. Detta framgår bl.a. av SPANEK-rapporten. I den preciseras ekonomisk brottslighet till att avse sådan brottslighet som har ekonomisk vinning som direkt motiv och som uppfyller följande förutsättningar:

1. har kontinuerlig karaktär och utförs på ett systematiskt sätt;

2. bedrivs i planerade och organiserade former;

3. förövas inom ramen för näringsverksamhet som i och för sig inte är kriminaliserad men som i det aktuella fallet utgör själva grunden för de kriminella handlingarna. ${ }^{5}$

Också jag själv deltog i denna definitionsdebatt. ${ }^{6}$ Jag menar fortfarande att det vid denna tidpunkt var förnuftig att göra en klar tudelning mellan »organiserad brottslighet « och »ekonomisk brottslighet« och ge begreppet ekonomisk brottslighet det innehåll som gjordes t.ex. i SPANEK-rapporten. Vid denna tid fanns det en ganska tydlig skiljelinje mellan den organiserade brottsligheten och de brottslingar som involverade sig i den och den ekonomiska brottsligheten och dess gärningsmän. Typiska organiserade brott var en hel del av narkotikabrotten, brott som handlade om illegal handel med tobak och alkohol, en del häleriverksamhet, koppleri och annan organiserad prostitution, lån med ockerräntor etc. Här handlade det om att syssla med verksamhet som bestod av gärningar som redan i sig - från första början - var kriminella. Den ekonomiska brottsligheten hade en annan karaktär: det handlar om kriminaliserade gärningar som begås i samband 
med lagenlig ekonomisk verksamhet. Dessa gärningar kan begås i samtliga skeden av de producerande processen: införskaffandet av kapital till ett ekonomiskt företag, vid anskaffandet av produktionsfaktorer, i samband med produktionsprocessen, vid marknadsföringen av produkter, vid återbetalning av kapital och vid erläggandet av skatter och avgifter.?

\section{Organiserad kriminalitet som ekonomisk kriminalitet}

Men verkligheten är inte statisk och det är något som också forskningen och dess begreppsbildning måste förhålla sig till. ${ }^{8}$ Med tiden kom med säkerhet »den organiserade brottsligheten « och »den ekonomiska brottsligheten « att överlappa och glida in i varandra allt mera. Inte heller begreppet »organiserad brottslighet« har haft något entydigt, allmänt accepterat innehåll. Med tiden kan man acceptera att den mest använda definitionen $\mathrm{i}$ vår del av världen är den operativa definition som används inom EU för att insamla data från medlemsländerna avseende brottssituationen och brottsutvecklingen. ${ }^{9}$ Denna definition består som känt av elva punkter, varav minst sex av kriterierna ska vara uppfyllda för att man ska kunna tala om organiserad brottslighet. Därtill krävs att några av punkterna alltid måste vara uppfyllda för att brott ska klassas som en del i organiserad brottslighet. Det gäller punkterna 1, 3, 5 och 11 som alltid måste finnas med och dessutom ska alltså minst två ytterligare kriterier vara uppfyllda: ${ }^{10}$

1. Samverkan mellan fler än två personer,

2. Egna tilldelade uppgifter till var och en av de samverkande personerna,

3. Lång eller obegränsad utsträckning $i$ tiden i fråga om den kriminella verksamheten,

4. Någon form av disciplin och kontroll bland de samverkande personerna,

5. Misstanke om allvarliga kriminella handlingar,

6. Verksamhet på internationell (gränsöverskridande) nivå,

7. Användande av våld eller andra metoder för hot $\mathrm{i}$ samband med den kriminella verksamheten,

8. Användande av kommersiella eller affärsmässiga strukturer för verksamheten,

9. Deltagande i penningtvätt,

10. Otillbörlig påverkan på politik, medier, offentlig förvaltning, rättsliga myndigheter eller ekonomin,

11.Strävan efter vinning och/eller makt.

Redan av denna definition framgår den hopsmältning mellan ekonomisk brottslighet och organiserad brottslighet som särskilt den senaste utvecklingen har lett 
till. Detta gäller särskilt kriterierna 8 och 9. Det som utmärker ekonomisk brottslighet har ju just varit att man använder sig av kommersiella eller affärsmässiga strukturer för den verksamhet inom vilken brotten begås, att man som det övergripande syftet med verksamheten har att maximera den egna ekonomiska vinningen och att man för att kunna tillgodogöra den ekonomiska vinningen också på olika sätt deltar i penningtvätt.

Sammanblandningen mellan organiserad brottslighet och ekonomisk brottslighet framgår också av empiriska belägg för hur den organiserade brottsligheten ser ut idag. De brott som begås inom den organiserade brottsligheten i Sverige är enligt tillgängliga uppgifter först och främst narkotikahandel, smuggling av sprit, tobak och dopingpreparat, stölder (bland annat handel med stulna bilar), handel med kvinnor - trafficking - och prostitution (kvinnor från Öst- och Centraleuropa samt Asien), illegal invandring, illegal spelverksamhet, vapenhandel och utpressning, grova rån och mord. Alla dessa brott är sådana som också traditionellt har ingått i den »organiserade brottsligheten«. Men därtill kommer ekonomiska brott (som skattebrott, karusellhandel, handel med skalbolag, handel med svart arbetskraft och bedrägerier) och i någon mån miljöbrott samt penningtvätt. ${ }^{11}$

Då vi granskar och begreppsbestämmer den organiserade brottsligheten och den ekonomiska brottsligheten ska vi alltså notera att det finns »organiserad brottslighet« som bedrivs som »ekonomisk brottslighet«. En del av den organiserade brottsligheten består alltså $\mathrm{i}$ att de verksamma etablerar sig som företagare som till synes bedriver »legal« näringsverksamhet. Verksamheten har ekonomisk vinning som direkt motiv och den har kontinuerlig karaktär och utförs på ett systematiskt sätt. Den bedrivs i planerade och organiserade former och - framför allt - de brott som begås förövas inom ramen för en näringsverksamhet som i och för sig inte är kriminaliserad men som i det aktuella fallet utgör själva grunden för de kriminella handlingarna.

Som exempel på denna utveckling, då personer som misstänks för organiserad kriminalitet involverar sig i »legal« ekonomisk verksamhet, kan nämnas att den danska polisen i samarbete med skattemyndigheter och sociala myndigheter i allt större omfattning har riktat sina brottskontrollerande åtgärder mot personer som man vet vara involverade i »rockernes«, alltså MC-klubbarnas, verksamhet som ledande personer. Den kontroll som man använder sig av är framför allt den s.k. »Al Capone-modellen«, m.a.o. man försöker målmedvetet gå efter den ekonomiska vinningen av en kriminell verksamhet genom samarbete mellan olika myndigheter.

I och för sig har det diskuterats om MC-klubbarna och deras brott verkligen ska betecknas som organiserad brottslighet. Ett kritiskt perspektiv på uppfattning- 
en att MC-klubbarna och deras medlemmar per se är kriminella förs fram i BR $\AA$ rapporten Organiserad brottslighet - lösa maskor eller fasta nätverk: ${ }^{12}$

"I den kriminalpolitiska och kriminalvetenskapliga diskussionen om organiserad brottslighet återkommer ofta frågan om mc-gäng (se till exempel SOU 2000:88, särskilt s. 75-88; se även BRÅ-rapport 1999:6). Hypotesen är då att viss brottslighet är relaterad till mc-gäng. Exempelvis konstateras att mcklubben xx utmärks av slutenhet, inre lojalitet och medlemmarnas speciella klädsel. Samtidigt finns personen yy som är medlem i klubben. Vid ett tillfälle misshandlar yy en annan person. Detta beskrivs då som ett brott som begåtts av en klubbmedlem i xx. Utgångspunkten är med andra ord att mcgäng och brottslighet bör sammanföras vid kriminalvetenskapliga analyser. Denna utgångspunkt innehåller alltså den symboliska påföljden att en för brott dömd eller misstänkt individ tillskrivs en viss grupptillhörighet, att personen i fråga kategoriseras utifrån vem vederbörande är, och inte utifrån av vad han har gjort. Annorlunda uttryckt: medlemmen i en mc-klubb är inte farlig på grund av sitt brott, utan brottet visar hur farlig han är [...]. Man definierar alltså mc-klubbar som en social kategori. För individuella medlemmar i mcklubbar innebär detta att de tillskrivs vissa typiska egenskaper. En av dessa anses vara en benägenhet att begå brott. Vidare medför kategoriseringen att ett eventuellt dokumenterat brott som begås av en individuell medlem i en mc-klubb kommer att beskrivas i termer av individens grupptillhörighet. Resonemanget går i cirkel. Genom en social kategori sker en kollektiv klassificering av individer som reducerar dem till medlemmar i en mc-klubb. När en av dessa individer begår brott beskrivs följaktligen denna brottslighet som brott av en medlem i en mc-klubb. Detta innebär i sin tur att kriterierna för kategoriseringen tycks vara riktiga. Tillsammans med den växelverkan som finns mellan kategoriseringen och de kategoriserades självbild och identitet făr denna process en tydlig självuppfyllande karaktär.«

Jag ska inte här ta upp den diskussionen. Men faktum är enligt de danska erfarenheterna att »flere af landets bedst kendte rockere driver helt åbenlyst selskaber« och att de också misstänks för kriminalitet i samband med detta. Vad det handlar om är bolag inom skilda former av näringsverksamhet: det handlar om ledande ställningar i flera flyttbolag och transportbolag, i bolag som utför tjänster som väktare, bolag som sysslar med städning och lokalvård, entreprenörverksamhet, bolag som utför murararbeten och andra uppgifter inom byggbranchen, importföretag (specialdelar till motorcyklar), företag som bedriver verksamhet som hyr ut egendom (möjlig bordelldrift), bolag som bedriver verksamhet på internet med bl.a. utbud på ett antal sidor med pornografiskt material, bolag som säljer kläder, frisörverksamhet och enskild verksamhet som tatuerare. ${ }^{13}$ Vad som ska tilläggas är att det att dessa personer bedriver denna typ av ekonomisk verksamhet inte i sig är bevis för att de också bedriver organiserad brottslighet i form av ekonomisk brottslighet - men misstanken finns där. Åtminstone i form av att det kan handla om penningtvätt. 
Också i den svenska Rikskriminalpolisens årsberättelse (2010) finns det information om sammankopplingen mellan organiserad brottslighet och ekonomisk brottslighet med hjälp av företag:

»Företag används i hög utsträckning av kriminella personer, dels för att generera pengar genom försäljning av varor eller tjänster, dels som front för att dölja pengars ursprung. Det är däremot ovanligt att de kriminella själva är formella företrädare för företagen. Det är i stället andra, exempelvis släktmedlemmar. Många gånger är företag en förutsättning för att kunna bedriva grov organiserad brottslighet. Ett exempel är smuggling i större skala, som omsätter mycket pengar och som ofta kräver samordnade transporter och tillgång till lager. Bedrägerier med hjälp av företag, till exempel genom illegalt utnyttjande av ROT-avdrag eller assistansersättning, beräknas omsätta miljardbelopp varje år. Ett annat sätt att använda företag för att begå brott är att betala ut lön till en person utan att han eller hon utför något arbete. Löntagaren får rätt till a-kassa, sjukpenning och andra sociala förmåner, och betalar arbetsgivaren med svarta pengar som motsvarar lönen. $\aleph^{14}$

Jag menar alltså att den tudelning som fanns mellan »ekonomisk brottslighet« och »organiserad brottslighet« inte längre är lika klar som den var en gång. Jag tog också konsekvensen av detta genom att överge min gamla snäva definition av »ekonomisk brottslighet« som näringslivets brottslighet. Också organiserade brott som begås inom ekonomisk verksamhet som bedrivs i skenet av full legitimitet ska beaktas när man bestämmer innehållet i begreppet ekonomisk brottslighet. ${ }^{15}$

\section{Organiserad kriminalitet, ekonomisk kriminalitet och terrorism}

»Terrorism《 är den tredje formen av brottslighet som ska granskas. Också i detta fall har det varit svårt - nästan intill omöjligt - att komma fram till en entydig, fullt accepterad definition av vad det är som avses. ${ }^{16}$ Idag finns det knappast någon anledning att inte acceptera den begreppsbestämning som finns i EU:s rambeslut av den 13 juni 2002 om bekämpande av terrorism (2002/475/RIF). Den definition av terrorgärningar som ges i rambeslutet (artikel 1) är som känt tudelad. Den innehåller först en allmän karaktäristik av terrorgärningar och sedan en lista över konkreta brottstyper som kan utgöra terrorbrott. I detta sammanhang är det den allmänna karaktäristiken som är av intresse och det som utmärker en terrorgärning enligt den är att det handlar om

- uppsåtliga handlingar

- som genom sin art eller sitt sammanhang allvarligt kan skada ett land eller en internationell organisation och 
- som begås i syfte att injaga allvarlig fruktan hos en befolkning, otillbörligen tvinga offentliga organ eller en internationell organisation att utföra eller att avstå från att utföra en viss handling, eller allvarligt destabilisera eller förstöra de grundläggande politiska, konstitutionella, ekonomiska eller sociala strukturerna $\mathrm{i}$ ett land eller $\mathrm{i}$ en internationell organisation.

Då det gäller terrorism finns det ett antal konventioner, internationella beslut och nationella lagar som utarbetats för att förebygga och förhindra terrororganisationer att verka. Det finns särskild anledning att nämna FN:s konvention av den 9 december 1999 om bekämpande av finansiering av terrorism. Konventionen har implementerats i den nationella lagstiftningen genom egna lagar. Här ska den svenska lagen nämnas, lag (2002:444) om straff för finansiering av terrorism och särskilt allvarlig brottslighet i vissa fall. Enligt lagen ska den som samlar in, tillhandahåller eller tar emot pengar eller andra tillgångar i syfte att dessa skall användas eller med vetskap om att de är avsedda att användas för att begå särskilt allvarlig brottslighet döms till fängelse i högst två år eller om brottet bedöms vara grovt, till högst sex år fängelse. Vid bedömandet av om brottet är grovt ska särskilt beaktas om det har utgjort led i en verksamhet som bedrivits i större omfattning eller annars varit av särskilt farlig art.

I lagen talas det alltså om »terrorism och särskilt allvarlig brottslighet«. Den definition som ges i lagen av dessa begrepp hänvisar i allt väsentligt till brott som kan utgöra terrorbrott.

Särskilt under det senaste decenniet har åtgärderna mot penningtvätt kopplats samman med åtgärder som gäller bekämpning av finansiering av terrorism. Den internationella arbetsgruppen för finansiella åtgärder mot penningtvätt (FATF) utökade i oktober 2001 sin verksamhet till att även omfatta finansiering av terrorism. Bland annat som en konsekvens av detta har nya normer utarbetats både internationellt och nationellt. Av de internationella instrumenten ska det s.k. tredje penningtvättdirektivet nämnas, alltså Europaparlamentets och Rådets direktiv av den 26 oktober 2005 om åtgärder för att förhindra att det finansiella systemet används för penningtvätt och finansiering av terrorism. Också detta direktiv har lett till nationell lagstiftning, i Sverige till den nya lagen (2009:62) om åtgärder mot penningtvätt och finansiering av terrorism. ${ }^{17}$

Till åtgärderna med syfte att förhindra eller åtminstone försvåra terrororganisationer att verka hör också EU:s beslut om särskilda restriktiva åtgärder mot vissa organisationer och vissa enskilda personer. Grundbesluten togs genom förordningar 2001 och 2002 och innehållet i besluten har sedan dessa ändrats upprepade gånger genom nya förordningar. De två viktigaste grundbesluten gjordes 
genom Rådets förordning (EG) nr 881/2002 av den 27 maj 2002 om införande av vissa särskilda restriktiva åtgärder mot vissa med Usama bin Ladin, nätverket alQaida och talibanerna associerade personer och enheter och om upphävande av förordning (EG) nr 467/2001 om förbud mot export av vissa varor och tjänster till Afghanistan, skärpning av flygförbudet och förlängning av spärrandet av tillgångar och andra finansiella medel beträffande talibanerna i Afghanistan, respektive Rådets förordning av den 27 december 2001 (EG) 2580/2001 om särskilda restriktiva åtgärder mot vissa personer och enheter i syfte att bekämpa terrorism. Samtidigt fattade ministerrådet beslut 2001/927/EG om att upprätta den förteckning över personer, grupper och enheter som avses i artikel 2.3 i nämnda förordning. Också denna förteckning har senare ändrats. ${ }^{18}$

Det finns skäl att också nämna nationella lagar som den svenska lagen (1996:95) om vissa internationella sanktioner. Lagen innehåller föreskrifter om nationellt genomförande av internationella sanktioner som har beslutats eller rekommenderats av Förenta nationernas säkerhetsråd i överensstämmelse med Förenta nationernas stadga, eller som har beslutats i överensstämmelse med de särskilda bestämmelserna om den gemensamma utrikes- och säkerhetspolitiken i fördraget om Europeiska unionen och som syftar till att upprätthålla eller återställa internationell fred och säkerhet. I lagen finns också föreskrifter som gäller förordningar om ekonomiska sanktioner som har beslutats av Europeiska unionen.

Då det gäller den »ekonomiska brottsligheten« och »den organiserade brottsligheten« kan vi alltså se en viss koppling och en sammanblandning. Men vad med terrorismen? Terrorismen är inte ekonomisk brottslighet som begås inom ramen för legal näringsverksamhet och definitionen av terrorism har inte heller några punkter som ingår i definitionen av ekonomisk brottslighet. Men terrorismen är otvetydigt en form för »organiserad brottslighet« och den uppfyller många av de kriterier som finns på EU:s lista över den organiserade brottslighetens kännetecken. Men syftet med terrorverksamhet är inte att skapa ekonomisk vinning utan syftet är att så starkt som möjligt föra fram ett samhälleligt, politiskt, budskap. De kopplingar som kan finnas mellan ekonomisk brottslighet, organiserad brottslighet och terrorism kan således främst handla om finansiering av terrorism och annat underlättande av terrorverksamhet.

\section{Brottsbekämpningen inom $\mathbf{E U}$}

EU har deklarerat sig som ett område för frihet, rättvisa och säkerhet. ${ }^{19}$ Inom detta område ska man också bekämpa brottsligheten. Det framgår tydligt redan av fördraget om Europeiska unionens funktionssätt. Enligt artikel 82 i fördraget ska 
»det straffrättsliga samarbetet inom unionen bygga på principen om ömsesidigt erkännande av domar och rättsliga avgöranden och inbegripa en tillnärmning av medlemsstaternas lagar och andra författningar på [ett antal utpekade områden].« De områden som harmoniseringsåtgärderna ska omfatta anges i artikel 83. Enligt den får europaparlamentet och rådet genom direktiv $i$ enlighet med det ordinarie lagstiftningsförfarandet fastställa minimiregler om fastställande av brottsrekvisit och påföljder inom områden med särskilt allvarlig brottslighet med ett gränsöverskridande inslag, som en konstaterad följd av att brottens karaktär eller effekter eller av ett annat särskilt behov gör det nödvändigt att bekämpa dem på gemensamma grunder.

De områden som räknas upp är terrorism och ett antal brottstyper som typiskt sett begås inom ramen för den organiserade kriminaliteten, alltså: terrorism, människohandel och sexuellt utnyttjande av kvinnor och barn, olaglig narkotikahandel, olaglig handel med vapen, penningtvätt, korruption, förfalskning av betalningsmedel, it-brottslighet och organiserad brottslighet.

Också då det gäller Eurojusts uppgifter görs i fördraget de facto en sammankoppling mellan terrorism och organiserad brottslighet. Eurojusts uppgift ska enligt fördraget vara att stödja och stärka samordning och samarbete mellan de nationella myndigheter som har till uppgift att utreda och lagföra allvarlig brottslighet som berör två eller flera medlemsstater eller som det krävs lagföring för på gemensamma grunder, på grundval av operationer som genomförs och information som lämnas av myndigheterna i medlemsstaterna och av Europol.

Sammankopplingen mellan organiserad brottslighet och terrorism är inte ny när det gäller EU:s brottsbekämpande åtgärder. Redan i preambeln till rambeslutet om bekämpande av terrorism uppräknas ett antal dokument och beslut som innehåller en sådan sammankoppling. Som exempel på sådana referenser i preambeln kan nämnas rådets och kommissionens handlingsplan av den 3 december 1998 för att på bästa sätt genomföra bestämmelserna i Amsterdamfördraget om upprättandet av ett område med frihet, säkerhet och rättvisa, slutsatserna från Europeiska rådet sammanträde i Tammerfors den 15-16 oktober 1999 och från Europeiska rådet i Santa Maria da Feira den 19-20 juni 2000, rådets beslut av den 3 december 1998 om att ge Europol i uppdrag att behandla brott som begåtts eller misstänks bli begångna i samband med terroristaktiviteter som riktar sig mot liv, hälsa, personlig frihet och egendom, rådets gemensamma åtgärd 96/610/RIF av den 15 oktober 1996 om att upprätta och föra ett register över specialiserad kompetens, skicklighet och sakkunskap när det gäller att bekämpa terrorism för att underlätta samarbetet om att bekämpa terrorism mellan Europeiska unionens medlemsstater, rådets gemensamma åtgärd 98/733/RIF av den 21 december 1998 
om att göra deltagande i en kriminell organisation i Europeiska unionens medlemsstater till ett brott samt rådets rekommendation av den 9 december 1999 om samarbete i kampen mot finansiering av terroristgrupper.

Också i ett antal senare rambeslut och dokument görs motsvarande sammankoppling - inte minst i dokument som gäller bekämpning av penningtvätt. På en informationssida som EU har haft (EU4Journalists. Background details and essential information about the European Union) kan man bl.a. läsa följande. ${ }^{20} \mathrm{Un}$ der rubriken »Organiserad kriminalitet och terrorism« anförs följande:

»Det er en af EU's vigtigste garantier, at alle borgerne skal føle sig sikre. Såvel praktiske som lovgivningsmæssige tiltag bliver brugt i kampen mod organiseret kriminalitet, narkohandel, terrorisme, hvidvaskning af penge og menneskesmugling. På den praktiske front samarbejder de nationale politistyrker i stigende omfang, især inden for rammerne af Europol. Europol er baseret i Haag og fungerer som koordineringscenter: det indsamler, analyserer og deler efterretninger om kriminelle aktiviteter for at styrke medlemslandenes kamp mod den alvorlige kriminalitet i hele EU.

Et alvorligt problem er hvidvaskning af penge. Introduktionen af euroen har gjort det lettere at flytte store summer penge fra illegale aktiviteter rundt i Europa uden at blive opdaget. Våbnet mod hvidvaskning af penge er skrappere lovgivning.«

Också här sammankopplas alltså de två brottsformerna. Fråga är om det finns reella empiriska belägg för att »organiserad brottslighet« och »terrorism« ibland bedrivs som ett gemensamt företag med gemensamma intressen.

\section{Ekonomisk kriminalitet, ekonomisk kriminalitet och terrorism}

Som nämnts ovan utökade den internationella arbetsgruppen för finansiella åtgärder mot penningtvätt (FATF) år 2001 sin verksamhet till att också omfatta finansiering av terrorism. I en rapport som FATF publicerade i juni 2012 menade organisationen sig kunna bevisa ett klart samband mellan illegal tobakshandel och terrorismfinansiering. ${ }^{21}$ I rapporten beskrivs den illegala tobakshandeln på följande sätt:

»The illicit trading of tobacco products is the supply, distribution and sale of smuggled genuine, counterfeit or cheap white tobacco products. In generic non-commodity specific terms, it works on the following principle - there is a financial incentive to source a product in a lower-priced market and transport, distribute and sell it in a higher-priced market. This can include international movements or within countries that allow for intra-community price differentials. Illicit trade in tobacco is made up of various activities. Smuggling is conducted for one or both of the following reasons: to avoid excise taxes, and to evade rules prohibiting the sale of such goods. [...]. The sophistication and complexity of the smuggling depends upon the size and ambition of 
the groups involved and the nature of the commodity. For example, some Organised Crime Groups (OCGs) will manage all aspects of the production process, from sourcing raw tobacco product, through to developing specific tobacco packaging that will generate suitable market interest and /or appear legitimate if counterfeit product. Others will rely on the work of key facilitators, often based overseas, who engage with smaller legitimate tobacco manufacturers in sourcing the tobacco goods and associated packaging. The OCG then agrees a distribution route with the facilitator and agrees risk mitigation mechanisms to ensure successful delivery. Certain groups simply exploit lower cross-border prices of genuine tobacco products and smuggle them to their chosen destination for sale.«

Det konstateras också att »tobacco smuggling is attractive to criminals (or opportunists), for several reasons, including the generation of large sums of money for criminal reinvestment or funding lavish lifestyles, and the perception of lesser punitive sanctions or penalties if caught smuggling.«

När det gäller kopplingen mellan illegal tobakshandel och finansiering av terrorism och belägg för att det finns en sådan koppling ger rapporten inte så mycket information. Det konstateras att "phony cigarette tax stamps were found in apartments used by the perpetrators in the 1993 bombing of the World Trade Centre in New York. «Och dessutom beskrivs ett konkret fall som gäller USA:

»Subject was born in Lebanon, moved to the United States illegally in 1992 and lived there by virtue of three sham marriages to US citizens until his arrest on 21 July 2000. Subject, along with two of his brothers and 22 others, were indicted and convicted of providing material support to Hezbollah, cigarette smuggling, money laundering, conspiracy, racketeering, and immigration fraud. His guilty verdicts rendered by the jury were upheld by the Supreme Court of the United States.

Subject was a student and member of Hezbollah as a youth in his home country and moved to the United States on a Hezbollah-driven mission. He accomplished his mission by creating a criminal enterprise which smuggled more than USD 8 million worth of cigarettes from North Carolina to Michigan with profits sent to Hezbollah in Lebanon. He purchased businesses in the U.S. and preached radical Muslim fundamentalism as he led a clandestine terrorist cell in Charlotte, North

Carolina and raised funds for the cause through cigarette smuggling.

During his imprisonment and while awaiting trial, he ordered the murder of the prosecuting attorney and the bombing of Charlotte's federal courthouse. The 2002 trial was the first in the country of a federal »material support to a designated terrorist organisation « charge.«

En möjlig koppling mellan illegal tobakshandel och terrorismfinansiering beskrivs också i ett BRÅ-dokument. ${ }^{22}$ Enligt sammanfattningen i rapporten handlar det inte så mycket om konstaterade samband utan mer om möjliga risker framför allt när det gäller existerande alternativa betalningsförmedlare. Jag citerar: 
»Vissa former av brott kan generera stora pengar, överskott som överstiger kostnaderna för den dagliga konsumtionen. För gärningspersonerna blir det därför nödvändigt att förvandla pengar från kriminell verksamhet till legitima medel för att dölja deras brottsliga ursprung och kunna investera medlen i den legitima ekonomin. Brottsliga vinster är således helt beroende av det etablerade samhället med dess institutioner, trygghet och reglering för att kunna förränta sig. Detsamma gäller svarta pengar som kommer från skattebrott.

För terrorfinansiering handlar det mer om att dölja pengarnas mottagare, som bedriver brottslig verksamhet, än pengarnas ursprung, som kan utgöras av helt lagliga löneinkomster eller har liknande bakgrund. Det finns därför ett behov av att tvätta pengar och få in dem i de reguljära betalningssystemen. Dessa system används också för penningtvätt. En metod som också används är att anlita så kallade alternativa betalningsförmedlare, som utgörs av privatpersoner eller småföretagare. De alternativa betalningsförmedlarna samverkar i nätverk som kallas för alternativa betalningssystem. Dessa alternativa betalningssystem ligger i vissa fall i praktiken utanför myndigheternas kontroll och därför är de intressanta för penningtvätt och terrorfinansiering. Efter terrordådet den 11 september 2001 har frågan om betalningssystemens användning för terrorfinansiering satt betalningsförmedlingen ytterligare $\mathrm{i}$ fokus. Utan att falla i gropen för det som forskaren Michael Levi kallar för »hotbedömningsindustrin« är syftet med denna kunskapssammanställning att peka på några risker som finns med de alternativa betalningsförmedlarna i fråga om penningtvätt och terrorfinansiering.«

I rapporten konstateras att de alternativa betalningssystemen också kan - och i praktiken förmodligen också används - genom att betalningsförmedlaren är inblandad i brottsligheten eller för »smurfing«, det vill säga när stora belopp delas upp i småsummor. Det är lätt att undvika valuta- och skattekontroller och det förs register över verksamheten på ett sådant sätt att användarna kan vara anonyma. Systemen används för bland annat narkotikaaffärer och korruption. Det konstateras att det för svensk del finns uppgifter om att alternativa betalningssystem används för kriminella syften men omfattningen är okänd. Ett troligt användningsområde uppges vara skatteflykt. En koppling mellan penningtvätt och terrorfinansiering är alltså inte något som beläggs med säkerhet i rapporten.

\section{Ekonomisk brottslighet och organiserad brottslighet samt terrorism i Norden: Är ekobrottslingarna och de organiserade kriminella också terrorister?}

Som anfört i inledningen till denna granskning bygger den inte på egen empirisk forskning. Men vad den bygger på är en granskning av några årsrapporter av de centrala brottskontrollerande myndigheterna i Danmark, Finland och Sverige. Tecknas det i dem några hotbilder som visar på en klar koppling mellan de tre brottslighetsformer som granskas? 
Vi börjar med Danmark. I Danmark ligger bekämpningen av terroristbrott först och främst hos PET, alltså Politiets efterretningstjenste. Här kan vi se på PET:s egen årsberättelse för information om vad man uppfattar som viktigt när det gäller att bekämpa terrorism i dess olika former. ${ }^{23} \mathrm{Vad}$ som finns i den är bl.a. en beskrivning av ett antal upptäckta terrorbrott i Danmark. De fall som beskrivs är det s.k. »Headley-fallet«. Det handlar om att två personer som enligt PET:s och FBI:s uppfattning förberedde ett omfattande terrorangrepp mot konkreta mål i Danmark, bl.a. Jyllands-Postens lokaler i Köpenhamn, greps och anhölls i Chicago, USA. De misstänkta personerna hade haft förbindelser till terrornätverken Lashkar-e-Taiba (LeT), al-Qaida och Harakat-ul-Jihad Islami (Huji). Enligt årsberättelsen ser såväl PET som de amerikanska myndigheterna »med mycket stort allvar på fallet«, inte minst på grund av att den ena av de misstänkta har tillstått att han hade deltagit i planläggningen av terrorangreppen i Mumbai, Indien, år 2008 och därtill hade han »haft kontakt med en tidigare major i den pakistanska armén«. Fallet utreds och behandlas av myndigheterna i USA.

Det andra fallet som beskrivs är ett överfall mot bladtecknaren Kurt Vestergard. Det var han som år 2005 väckte stor misshag som upphovsman till karikatyren av profeten Mohammed. Vad det handlar om är att en somalisk man, som var fast bosatt i Danmark, en kväll beväpnad med en yxa och en kniv trängde in i Vestergaards hem, uppenbarligen med uppsåt att döda honom. Mannen dömdes för terrorbrott till fängelse i nio år.

Det tredje fallet handlar om ett bomdåd i Köpenhamn, »bombesprængning på Hotel Jørgensen«. Fallet handlade om en man som av misstag utlöste en hemmagjord bomb i en hotellkällare. Polisen bedömning var att mannen, en 24-årig belgisk medborgare med tjetjensk bakgrund, hade försökt framställa en brevbomb som skulle användas mot Jyllands-Postens lokaler och anställda. Då bomben detonerade skadades mannen själv svårt. Mannen dömdes för terrorism till fängelse i 12 år.

I berättelsen beskriver man också vissa »övriga danska terrorsaker«. De handlar om »Boghandleren fra Brønshøj« som anhölls 2005 och som senare dömdes för uppmaning till terrorhandlingar, »Glostrup-sagen « som handlade om fyra personer som anhölls misstänkta för terrorism - tre av dem frikändes men en dömdes till fängelse i sju år, »Vollmose-sagen« som handlade om misstänkt försök till terrorism - ett fall som ledde till att två av flera anhållna personer dömdes till fängelse i 12 år respektive 8 år, ett fall om misstänkt terrorism som undersöks tillsammans med norska myndigheter och slutligen ett anhållande av tre personer som misstänktes vara i beråd att begå ett terrorbrott riktat mot Jyllands-Posten. 
Sistnämnda fall beskrivs också i årsberättelsen för den svenska Rikskriminalpolisen.

Det framförs inte i beskrivningarna av något av dessa fall en misstanke om en möjlig sammankoppling mellan organiserad brottslighet eller ekonomisk brottslighet och terrorbrotten. PET:s årsberättelse innehåller inte heller i övrigt något som gäller en möjlig koppling av detta slag. Inte heller i det avsnitt som behandlar PET:s insatser när det gäller den organiserade brottsligheten.

I detta avsnitt av årsberättelsen upplyses det att »den form for organiseret kriminalitet, PET beskæftiger sig med, er kendetegnet ved sin internationale, grænseoverskridende og professionelle karakter. Ydermere bliver kriminaliteten begået under anvendelse af vold, trusler og våben, og oftest i svært tilgængelige miljøer, hvor gerningsmændene er meget sikkerhedsbevidste.« Man kunde på goda grunder anta att detta just gäller en möjlig sammankoppling mellan organiserad brottslighet och terrorbrott. I årsberätellsen konstateras också att PET:s aktivitet på detta område skall medverka »til at sikre efterretningstjensten et grundlag for, på et så tidligt tidspunkt som muligt, at kunne identificere eventuelle relationer mellem den alvorligste organiserade kriminalitet herhjemme og efterretningstjenstens øvrige arbejdsområder«. Men några konkreta belägg för en koppling mellan ekonomisk brottslighet, organiserad brottslighet och terrorbrott läggs såleds inte fram.

En granskning av den svenska säkerhetspolisens årsberättelse för 2011 (Säkerhetspolisen 2011) ger samma resultat. Också i den finner vi några beskrivningar av aktuella terrorbrott, men i dem finns inte något bevisat samband mellan de former för brottslighet som behandlas här. Också i den svenska Regeringens skrivelse »Ansvar och engagemang - en nationell strategi mot terrorism《 som publicerades 2012 beskrivs vissa konkreta terrorbrott. Det handlar delvis om samma brott som beskrivs i den danska PET:s berättelse.

»En sprängladdning detonerade i centrala Stockholm den 11 december 2010. Självmordsbombaren omkom. I Norge användes en egentillverkad bomb och skjutvapen för att ta 77 människors liv den 22 juli 2011. Ett terroristattentat mot en tidningsredaktion i Danmark kunde förhindras kort tid före dess fullbordan tack vare effektivt arbete i Sverige och samarbete med myndigheter i Danmark. Gärningsmännen, däribland tre svenska medborgare, greps i december 2010. Terroristattentaten och försöket var riktade mot de värden som vårt samhälle bygger på. Det är viktigt att hotet från terrorism bemöts med förebyggande åtgärder, väl samordnade förberedelser och en förmåga att förhindra attentat.«

Då det gäller terrorismbekämpning i övrigt ges Samverkansrådet mot terrorism mycket uppmärksamhet. Vad det handlar om är ett samarbete mellan fjorton 
svenska myndigheter, som syftar till att stärka Sveriges förmåga att motverka terrorism. Rådet skapades på initiativ av Säkerhetspolisen, och det leds av Säkerhetspolisens generaldirektör. Där deltar även de högsta cheferna för Rikskriminalpolisen, Försvarsmakten, Försvarets radioanstalt, Totalförsvarets forskningsinstitut, Myndigheten för samhällsskydd och beredskap (MSB), Kustbevakningen, Tullverket, Ekobrottsmyndigheten, Migrationsverket, Strålsäkerhetsmyndigheten, Kriminalvården, Åklagarmyndigheten samt Transportstyrelsen. Rådets sammansättning antyder alltså en misstanke om ett möjligt samarbete mellan ekobrottsligheten, den organiserade brottsligheten och terrorbrotten.

Det finns också en viss information om den organiserade brottsligheten, framför allt i Rikskriminalpolisens årsberättelse. Den information vi finner där är att »en sammantagen bedömning är att den grova organiserade brottsligheten fortsätter att öka och att de kriminella använder alltmer sofistikerade metoder i sin verksamhet «. Men vad brottsligheten handlar om har inte omedelbara kopplingar till terrorism: »De grovt kriminella riktar främst in sin verksamhet på narkotikahantering $\mathrm{i}$ alla dess former, människohandel och människosmuggling, varusmuggling, grova stölder och rån, utpressning och beskyddarverksamhet samt ekonomisk brottslighet.«

Om vi sedan går till den finska säkerhetspolisens årsberättelse (»Skyddspolisens SUPO årsberättelse $2011 \ll$ ) blir resultatet helt detsamma. I berättelsen hänvisas till att planerade terrordåd avslöjades och terroristceller spårades och upplöstes bl.a. i Sverige, Norge, Danmark, Nederländerna, Frankrike, Tyskland och Storbrittanien, men att de personer som låg bakom de avslöjade och brutna terrorismplanerna samt de terrordåd som försöktes begås inte kunde konstateras ha några förbindelser till Finland. Också i övrigt bedöms terrorhoten mot Finland att vara lägre än mot de andra nordiska länderna och vissa andra stater i Europa. »I ljuset av de erfarenheter som fåtts under översiktsåret är det allmänna hotet från radikalislamistisk eller annan terrorism lågt mot Finlands statliga strukturer, kritiska infrastruktur och befolkning.«

\section{Finansiering av terrorism}

Den närmaste koppling som man i efterrättningstjänsternas årsberättelser kan finna mellan ekonomisk brottslighet, organiserad brottslighet och terrorism gäller finansiering av terrorism. Vissa indikationer på detta kan läsas in i konkreta exempel i alla tre årsberättelser i denna granskning.

I PET:s berättelse refereras följande fall: 
»I marts 2009 blev seks personer fra tøjfirmaet Fighters+Lovers i Højesteret fundet skyldige i terrorfinansiering i forbindelse med salg af t-shirts til fordel for FARC og PFLP. De blev alle straffet med betingede fængselsdomme.

I marts 2010 blev Foreningens Oprørs talsperson i Københavns Byret idømt en betinget fængselsstraf for forsøg på overtrædelse af straffelovens bestemmelser om terrorfinansiering i forbindelse med indsamling af penge til fordel for FARC og PFLP.«

Det första fallet handlade om att ett litet bolag som en grupp bestående av sju personer har startat. Bolaget producerar kläder under sitt eget varumärke samt musik. De upplyser helt öppet att de stöder organisationerna FARC och PFLP. Fighters+Lovers producerede 2006 t-shirts med FARC:s och PFLP:s logo till fördel for de två organisationerna. Skjortorna kostade 170 kronor och av dessa kronor sändes vinsten per skjorta (som beräknades vara 37 kronor) oavkortade till organisationerna. Bolaget uppgav offentligt att »målet med det kontroversielle tshirtsalg var at gøre op med terrorbegrebet. Vi har gjort det for at gøre opmærksom på, at frihedskamp ikke er terrorisme, og at solidaritet ikke skal gøres til en forbrydelse.«

Det andra fallet handlade bara om en insamling av pengar för ett bestämt ändamål. Ett annat motsvarande fall beskrivs i den danska pressen i september 2012. Det handlar om frivilliga donationer från personer med en kurdisk bakgrund som har insamlats av en kurdisk exilorganisation i Danmark (»Dansk Folkesamling«) för att finansiera PKK:s kamp för kurdisk självständighet. Enligt polisen uppskattning handlar det om sammanlagt 67 miljoner kronor.

I den svenska skyddspolisens årsberättelse hänvisas också till misstänkt terrorfinansiering genom insamling av pengar.

»Det finns ett antal personer som misstänks stöda eller finansiera terrorbrott i andra länder - och detta gör de från Sverige. Av internationella konventioner följer ett folkrättsligt ansvar för Sverige att motverka sådana terrorbrott. Den terror-relaterade verksamheten i Sverige domineras av aktörer som är motiverade av vålds-bejakande islamistisk extremism, där syftet ofta är att stödja terrorbrott i konfliktområden, som till exempel Irak, Afghanistan och Somalia.«

Motsvarande misstankar framförs också i den finska skyddspolisens årsberättelse som också innehåller viss upplysning om ett konkret fall. Men problemet med att finna en säker sammankoppling mellan ekonomisk brottslighet, organiserad brottslighet och finansiering av terrorism är att de insamlade medlen inte automatiskt kan hänföras till illegal vinning av ekonomiska brott eller av organiserad brottslighet. Det är lika sannolikt att det handlar om insamling av pengar motsvarande dem som i andra fall görs för olika behjärtansvärda ändamål. 


\section{Avslutning}

Denna lilla granskning visar att det inte finns något klart empiriskt stöd för en sammankoppling mellan ekonomisk brottslighet, organiserad brottslighet och terrorism. Den springande frågan blir varför man i skilda dokument gör en sådan sammankoppling. Mitt bud är att det finns två huvudsakliga skäl till detta.

Det första handlar om en riskbedömning. Rent rationellt ligger det nära till hands att utgå från att illegal vinning från ekonomisk brottslighet eller pengar som kommer från organiserad brottslighet används eller kan användas för att täcka kostnaderna för terrorverksamhet. En grupp som har ambitionen att begå terrordåd behöver också en viss finansiering för detta och varför skulle man inte använda vinning av annan brottslighet till detta. Den BR $\AA$-rapport om risken med alternativa betalningssystem som nämnts ovan i avsnitt 6 handlar om en sådan riskvärdering.

Det andra skälet handlar om »marknadsföring « av nya - ofta integritetskränkande - kontrollåtgärder mot brottslighet. Här använder man »terrorism« och terrorhot som »brand «. Terrorismen är farlig och hot om terrordåd inger rädsla. Detta är i själva verket det som karaktäriserar terrorismen: det som i grunden utmärker en terrorgärning är att den ska vara skräckframkallande. ${ }^{24}$ Det betyder att det finns ett starkt argument för att öka kontrollen och repressionen mot brott om dessa brott kan sammankopplas med terrorism. Sådana »hårdare tag « mot brottslingar och vissa brott accepteras enklare av medborgarna i allmänhet - också om de innebär integritetskränkningar och kostnader också för dem - om de kan motiveras med sådan rädsla som terrorismen medför och sådana hot som terrordåden allmänt sett uppfattas innebära.

\section{Noter}

1. Per Ole Träskman (LL.D., doctor hc.) is senior professor of Criminal law at the University of Lund (Sweden) and associate professor of criminal law and criminal procedure at the University of Helsinki.

2. Sven-Åke Lindgren: Ekonomisk brottslighet. Ett samhällsproblem med förhinder. Studentlitteratur (2000), s. 45.

3. Ibidem, s. 47.

4. Ibidem, s. 48. Se också P.O. Träskman: Straffrätt och ekonomisk brottslighet. Festskrift till Hans Thornstedt. Norstedts (1983), s. 675-708.

5. Ibidem s. 48 och framför allt Rikspolisstyrelsen. Rapport 1979-05-25, C-429-2295/78, s. 3-5.

6. Se P.O. Träskman: Ekonomins kriminalitet: arbetsmaterialför sektion 3. Straffesystemer i Norden: konference arrangeret av Nordisk råds præsidium. Hotel Nyborgstrand 22-24 maj 1977. NU-serien B; 1977:25, s. 179-191; Per Ole Träskman: Ekonomins kriminalitet. Rapport från Nordiska Samarbetsrådets fær kriminologi forskarseminarium: 4-7 oktober 1976 i Udde- 
valla, Sverige, s. 15-26; Per Ole Träskman: En modell för forskning av ekonomins kriminalitet. Ekonomisk brottslighet: rapport från en konferens den 12 och 13 februari i Stockholm. BRÅ rapport 1979:1, s. 51-60 och Per Ole Träskman: Straffrätt och ekonomisk brottslighet. I Festskrift till Hans Thornstedt. Norstedts förlag (1983), s. 675-708.

7. Lindgren a.a., s 102 och s. 129; Bo Svensson: Ekonomisk kriminalitet. Tholin \& Larsson (1983).

8. Se också Per Ole Johansen: Organisert kriminalitet - Hva nå? NTfK 2008, s. 258-278; Paul Larsson \& Lars Korsell: Organisert kriminalitet, en kunskapsstatus. NTfK 2010, s. 443-454.

9. Se 6204/2/97 Enfopol 35 Rev 2 .

10. Notera att de obligatoriska kriterierna som alltid ska vara uppfyllda är kursiverade.

11. Ds 2008:38 Nationell mobilisering mot den grova organiserade brottsligheten - överväganden och förslag; Lars Korsell, Johanna Skinnari, Daniel Vesterhav: Organiserad brottslighet i Sverige, Liber (2009); Säkerhetspolisen: Den grova organiserade brottslighetens otillåtna påverkan på det demokratiska statsskicket. En första nationell hotbild, 2009.

12. Rapport 2002:7, s. 42.

13. Se www.business.dk/oekonomi/rockernes-selskaber

14. Rikskriminalpolisens årsberättelse 2010, s. 8-9.

15. Per Ole Träskman: Bestraffning av transnationella brott som begås i vinningssyfte. Erhvervsstudier - Business Law Essays. Copenhagen: Law Department, Copenhagen Business School, 1994, s. 167-180.

16. P.O. Träskman: Skräckbrottslingar och brottsskräck. NTfK 1986, s. 452-464.

17. Beträffande åtgärder mot penningtvätt och problem med dem, se Paul Larsson \& Dan Magnusson: Hvitvaskningsreguleringens kostnader. NTfK 2009, s. 3-25.

18. På EU:s lista över organisationer som ska anses vara terrororganisationer finns sammanlagt c. 50 organisationer. Några av dem är välkända (t.ex. Euskadi ta Askatasuna (ETA) (»Baskien och frihet«) Hamas (inklusive den väpnade grenen Hamas-Izz al-Din al-Qassem) Kurdistans arbetarparti (PKK),Tamilska befrielsetigrarna (Liberation Tigers of Tamil Eelam, LTTE) Palestinska folkfronten (Palestine Liberation Front, PLF) och Colombias väpnade revolutionära styrkor (Fuerzas armadas revolucionarias de Colombia, FARC), medan andra är mindre kända (t.ex. Kahane Chai (Kahane lever) och Khalistan Zindabad Force.

19. Se också Per Ole Träskman: Finsk, svensk och nordisk straffrätt - och den europeiska några reflektioner. I Tatu Hyttinen, Antti Jokela, Jussi Tapani \& Mikko Vuorenpää (red.): Rikoksesta rangaistukseen. Juhlajulkaisu Pekka Viljanen 1952 - 26/8 - 2012, Turun yliopisto. Oikeustieteellinen tiedekunta (2012), s. 257-270.

20. http://www.eu4journalists.eu/index.php/dossiers/danish/C45/197/

21. FATF guidance. Illicit Tobacco Trade. June 2012, www.fatf-gafi.org/media/fatf/documents/ reports/Illicit $\%$ Tobacco $\% 201$.

22. WEBBRAPPORT 2006:2. Penningtvätt och finansiering av terrorism. Kunskapssammanställning av betalningssystemens användning.

23. PET:s årsberetning 2008-2010.

24. Se P.O. Träskman: Skräckbrottslingar och brottsskräck. NTfK 1986, s. 254-257. 